\title{
The European fortifications on the coast of the Pacific Ocean
}

\author{
Nikolay Kasyanov, Research Institute of Theory and History of Architecture and Urban Planning \\ of the Russian Academy of Architecture and Construction Sciences, Moscow, Russia
}

\begin{abstract}
In the Russian Empire during XIX and early XX centuries, fortresses were built and strengthened along the frontiers. We studied the architecture of the Far Eastern Russian cities-fortresses using as examples Nikolaevsk-on-Amur, Port Arthur (now Luishun) and mainly Vladivostok. Coastal fortresses significantly influenced the urban development of the Far Eastern cities. The architectural peculiarity of the fortress architecture at that period was associated with the transition from the brick and stone fortifications to the complex systems of monolithic reinforced concrete. In 1860, a military post with the expressive and geopolitically ambitious name "Vladivostok" ("Possess the East") was established. By the beginning of the XX century, Vladivostok became a rapidly growing city of the European culture and one of the most powerful marine fortresses in the world. The Vladivostok Fortress was an innovative project in early XX century and has distinctive features of the modern style (Art Nouveau), partly of the Russian and classical style in architecture, as well as an organic unity with the surrounding landscape. Plastic architectural masses with their non-linear shape are typical of the fortifications of Vladivostok. Vast and branching internal communication spaces link fort buildings, scattered on the surface and remote from each other. Huge, monumental forts located on the tops of mountains and fitted perfectly in the landscape are successful examples of landscape architecture. The Vladivostok Fortress was the last huge marine citadel of the Russian Empire but not completed and turned into a Utopia. Now Vladivostok Fortress is proclaimed a monument to the past and architecture of the Russian Federation. Today, after nearly 100 years, a new large-scale innovative program for Vladivostok is being implemented, with the development of the adjacent island territories and the construction of modern large-span bridges.
\end{abstract}

Keywords: marine fortress, architecture, Pacific Ocean, Port Arthur, Vladivostok

The world history of the defensive architecture can be traced back through fortifications changing each other for several generations and the dependence of their forms on the development of military and construction technologies is clearly identifiable, defining both the constraints and new opportunities in the architectural form creation and urban planning. Thus, the large, kilometers-long diameters of forts allowed enough freedom to develop urban planning for cities within their perimeter. Such fortresses were often constructed around the existing cities with an established building structure. A feature of marine fortresses was the need for a good, sheltered bay with the takings to the sea, covered with islands and capes. The Russian military defensive architecture has long been developed in conjunction with the architecture of its time and had been influenced by architectural traditions. By the end of the $19^{\text {th }}$ century, it was concluded that the traditional brick fortifications were unsuitable. A short but important and striking final stage can be singled out in the evolution of fortresses - concrete defensive architecture at the turn of the $19^{\text {th }}$ and $20^{\text {th }}$ centuries.

In the Russian Empire of the $19^{\text {th }}$ and early $20^{\text {th }}$ centuries, fortresses were built and improved on the border areas, especially in its European part. The protection of coastal areas and major cities was conducted in the Baltic and Black Seas, as well as the Pacific Ocean (Fig. 1). During the expansion of the Russian Empire, the Russian vector and, thus, the European influence had reached, as we know, Harbin, Port Arthur, the Far East in Asia (China), California, Alaska in America, and even Hawaii. In 1860, Ensign N.V. Komarov and Lieutenant G. H. Egersheld with a detachment of soldiers and sailors founded a military post, receiving an expressive and geopolitically ambitious name "Vladivostok". The other posts were named Slavyanka and Novgorod. Such geographical names as the bay of Peter the Great and America (now Nakhodka Bay), Eastern Bosphorus Strait, the islands Russky, Askold, the bays Zolotoy Rog, Olga, Vladimir, Voyevoda, Vityaz, Boyarin, París, Patroclus, Diomedes, Ulysses, Ajax were given by Russian military and civilian researchers using historical, geographical, and even mythological reminiscences. By the early $20^{\text {th }}$ century, movement of Russia to the East was completed. On the coast of the Pacific Ocean, the defensive development priorities were sequentially received by Okhotsk, Petropavlovsk in Kamchatka, Nikolayevsk-onAmur, Vladivostok, Port Arthur, and with its loss - again Vladivostok.

In this area, there were military and research vessels of different countries, in particular, English. It is curious that the British managed to give their names to certain geographical points, for example, the archipelago of Empress Eugenia (RimskyKorsakov Islands), Cape Sandy, Termination Island. 


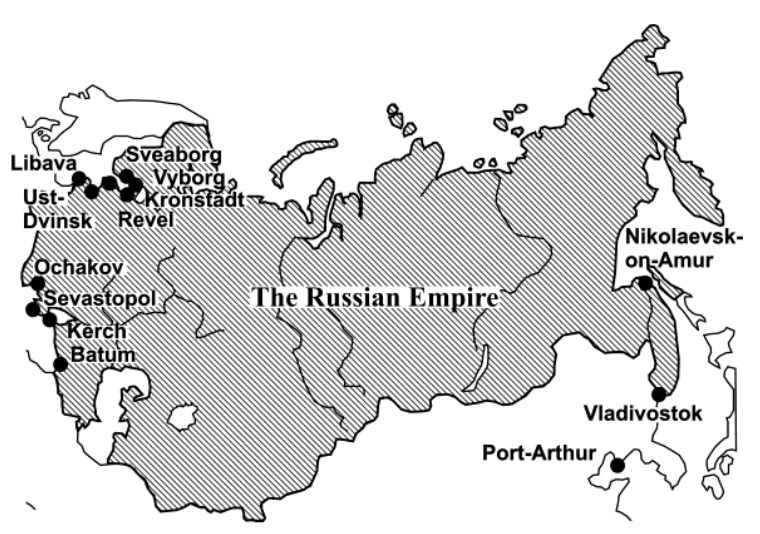

Fig. 1. Coastal fortresses of the Russian Empire in the beginning of XX century

[Source: from author private archive]

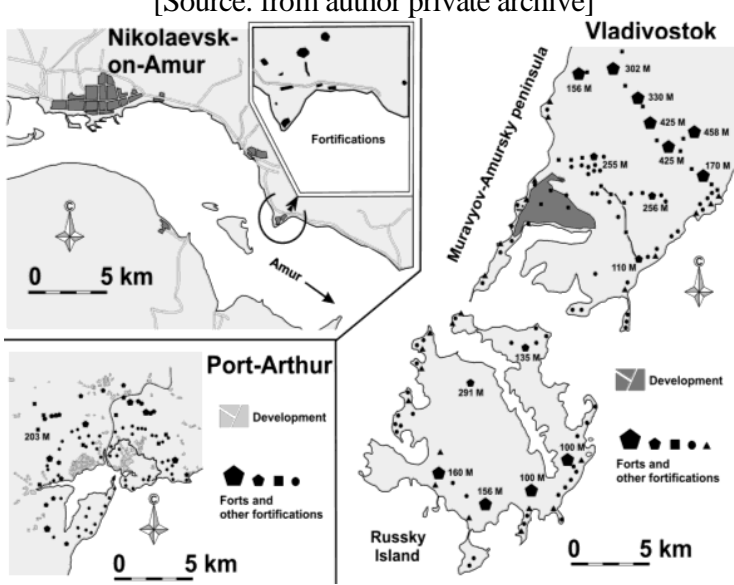

Fig. 2. Schemes of Far Eastern cities-fortresses: Nikolayevskon-Amur (top left); Port Arthur (bottom left); Vladivostok and its system of fortifications on the Muravyov-Amursky'

Peninsula and the Russian Island, to the right

[Source: material from author private archive]

This island is near Vladivostok, later named - Askold.

It is necessary to note the amazing beauty of the nature of these places, especially the Khasansky region - a rugged, rocky coastline on which the Korean grave pines grow, interspersed with rocky and sandy bays and coves with emeraldgreenish pure water. A lot of different marine organisms and animals live here, some of which are listed in the Red Book. Among the "Hills of Manchuria", there are the habitats of the Far Eastern leopards, tigers, and spotty deer.

The area of the present Far East with significant reserves of minerals, forest, and fishery resources by the middle of the XIX century, when the Ussuri region was finally incorporated into the Russian Empire, was practically undomesticated. The domestication of the region began during the development of capitalism almost simultaneously with the abolition of serfdom - which did not exist in the Far East. The Russian government sought to gain access to the ice-free seas. The foundation in 1850 of the Nikolaevsky Post at the mouth of the Amur actually confirmed the belonging of the Amur Region to Russia and formed a new river outlet of Russia to the Pacific Ocean. The Nikolaevsky Post was named Nikolayevsk-onAmur and became a military port and residence of the military governor. By the end of the $1850 \mathrm{~s}$, the port of Nikolayevsk-on-Amur was begun to be visited by merchant ships from San Francisco, Boston, and Hamburg. The city was actively developing, its area to the beginning of the 20th century amounted to 420 acres. In the city, there were 189 quarters, 24 streets, and 5 lanes [1]. Almost an orthogonal network of streets of Nikolayevsk-on-Amur was slightly bent, repeating the outlines of the banks of the Amur. The fortress was characterized by a combination of two fronts: the river one with coastal batteries and the land one with redoubts and other fortifications. Engineers tried to make maximum use of the terrain with coastal hills up to 160 meters in height. The main objects of the future fortress, defending the mouth of the Amur, were built on the left bank, on Chnyrrah Cape (Fig. 2). Wood-and-earth fortifications of a semi-long-term nature were erected. This fortress, which provided the possibility of safe construction of Nikolayevsk-on-Amur, did not have a direct effect on the development of the planning structure of the city itself since its main structures were concentrated closer to the mouth of the Amur [2, 3].

In the late $19^{\text {th }}-$ early $20^{\text {th }}$ centuries, there was a kind of "competition" between Russia and Germany, two superpowers of that time, involving the Asia-Pacific region as well. In 1897, the Chinese city of Qingdao was transferred under the concession of Germany and turned into a fortress and a strategically important port by the Germans. With the aim of domestication of the new areas of Russia and their economic development in the late $19^{\text {th }}$ century, the program of the settlement of the Far East by peasants from the European part of the Empire operated. Russia built the Trans-Siberian Railway and the Chinese-Eastern Railway. For access to the non-freezing Yellow Sea in 1898, the Tsarist Government of Russia leased a part of the Liaodong Peninsula from China for 25 years, with a view to locate the Russian military-naval Port Arthur fortress and the trading port Dalniy there. The future city-fortress was surrounded by two mountain ranges, with heights of up to $200 \mathrm{~m}$ above the sea level. The plan of 1898 to build a fortress included landlines of defense stretching around $70 \mathrm{~km}$ and the garrison with at least 70 thousand people, however, it was rejected as being too expensive. As a result, the landline of the defense, designed by Professor K. I. Velichko amounted to only about $19 \mathrm{~km}$ [3]. In his report, he wrote, "Such a topography, soil, and surface characteristics were not seen in any of our fortresses" [4, 222]. The completion of the 
construction works was scheduled in 1909; the total value of the fortress was to make about 15 million roubles. The line of the designed fortifications was placed on the tops of the mountains surrounding the bay and the city in a semicircle (Fig. 2).

The plan of the city was not orthogonal, areas with rectangular blocks clustered around several squares at the intersection of the major streets. The planning took into account the local landscape, part of the streets was entered in the terrain, though many of them were tried to be made straight. The panorama of the city was limited to high and steep hills, surrounding it in the perimeter. Innovations of the military architecture were linked there with the need to design and construct a fortress in the conditions of the difficult, mountainous terrain. The new forms brightly emerged in the cast concrete buildings of the coastal batteries with crossbars and direct through tambours with rounded corners, broad, expressive in plastic stairs to the cannon yards with concrete parapets. The traditional architectural decoration was also applied: embrasures of forts were built of stone, the walls of the fortification were coated with stone, topped with massive cornices. They are characterized by delicate decorating and architectural processing, profiling of many ancillary parts and structures.

The planning structure of the urban centers, integrated in the early $20^{\text {th }}$ century by the Russian architects in the cities of Port Arthur and Dalniy is still evident in the present Lushun and Dalian. The names of the streets in Dalniy symbolized the relationship of the new city built by the Russians with Russia - Petersburg Quay, Moskovskoye shosse, Kievsky, Vladimirsky, and Moskovsky Prospects, Red Square [5, 6, 7]. In Lushun, a significant number of Russian fortifications has been preserved, dominating on the tops of coastal hills above the city.

In 1904, the fortress of Port Arthur was actually half-built. For the purpose of saving money, the diameter of the fortress did not meet the necessary requirements, and the whole city with the port could be pierced through by the artillery of the enemy. From the harbor, there was only one narrow exit, and the outer roadstead was fully opened. Having withstood the storms, on December 20, 1904, the fortress (old style) was occupied by the Japanese.

In the meantime, Vladivostok was built at the southwestern extremity of the peninsula reaching into the Sea of Japan, which reaches a length of about $30 \mathrm{~km}$, the width of about $15 \mathrm{~km}$. A city with a well-protected harbor located on the banks of the Golden Horn Bay, reaching $7 \mathrm{~km}$ into the peninsula (Fig. 2). In 1862, the post of Vladivostok officially became a port with the right to the duty-free trade of foreign goods, which contributed to the development of the international trade. The first Russian immigrants arrived by sea to Vladivostok in 1865 . The Muravyov-Amursky Peninsula is washed by the Amur Bay from the east and Ussuri Bay from the east. The city has a good external raid and two exits in these bays, separated by a group of islands that make up as if a continuation of the MuravyovSmursky Peninsula [8, 9, 10]. In contrast to Port Arthur, here on one bay, the commercial and military port was located.

The first general plan of Vladivostok with an orthogonal network of streets and the squares of city blocks was designed in 1868. The rectangular quarters of the urban building are the result of great work in moving land masses for straightening the streets and reducing their slopes. In 1871, by the Government decision, Vladivostok becomes a Navy base and the main port of Russia in the Pacific Ocean but in 1873 - a base of the Siberian Flotilla. Having received the city status in 1880 , by the end of the $19^{\text {th }}$ century, Vladivostok became the center of numerous projects related to the development of the Eastern Siberia territories, fisheries, mining. The interest of foreign powers to the territory required strengthening of the positions of the Russian Empire on the shores of the Pacific Ocean. For this purpose, in 1899, Vladivostok was proclaimed a naval fortress, over the fortifications of the city a flag was raised $[8,11]$.

By the end of the $19^{\text {th }}$ century, Vladivostok turned into a booming city of European culture, formed due to the intense activity of Russian military engineers-architects, the officer corps, and business people who migrated from the European part of Russia and the Western Europe, mostly from Germany. In the center of Vladivostok, a continuous construction of buildings in the European architectural style was started [12]. There is an interesting comment by Professor of Washington State University (Pullman City) B. Ingemanson, " At that time, Vladivostok was a thriving international center. The proximity of vast natural resources, a large convenient port, and the railway contributed to the development of trade, flourishing of astounding architecture and significant recovery of industry"[13, 14] (Fig. 3).

Between the Russian Black Sea ports and Vladivostok, ships sailed carrying migrants and goods, then the construction of the Trans-Siberian railway was completed. The domestic architectural idea is part of the European-wide spiritual culture and the flow of culture from West to the East, reaching the Far East of the Asian continent, informed of the trends of the Western architecture.

Regular communication between Vladivostok with its status as "Porto Franco" and other ports gave a communications system to the international trade, due to which the city began to grow. 


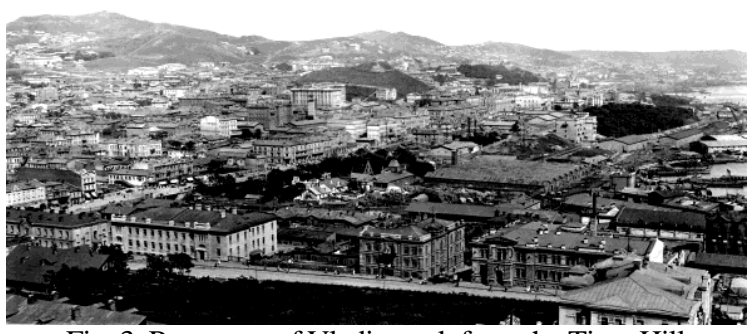

Fig. 3. Panorama of Vladivostok from the Tiger Hill, 1919-1920 [Source: from Ancha et al., 2009]

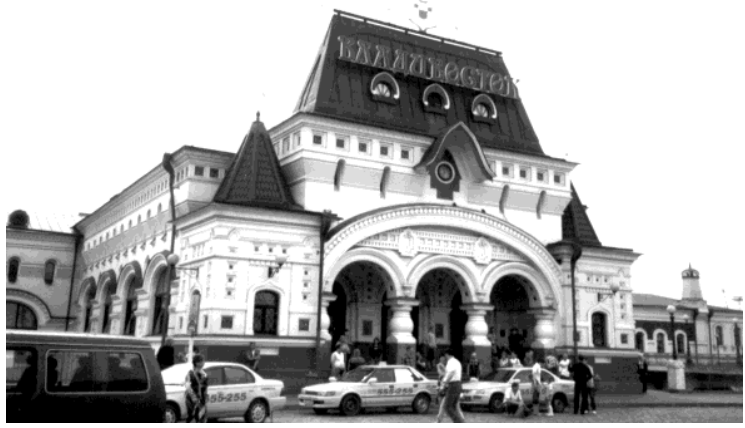

Fig. 4. Railway station in Vladivostok (1909-1911) [Source: material from author private archive]

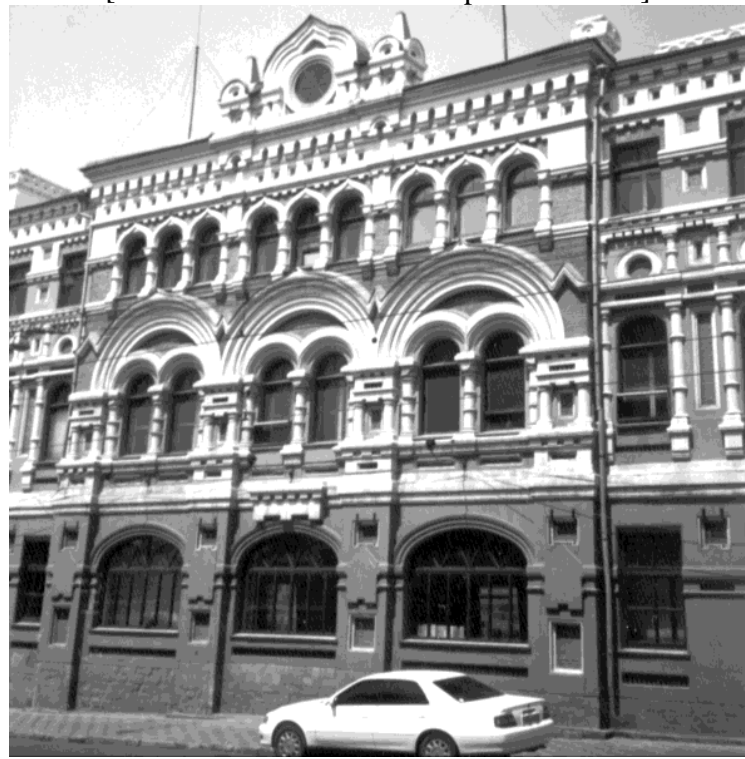

Fig. 5. Post Office building

(1900, the architect AA Gvozdziovsky)

[Source: material from author private archive]

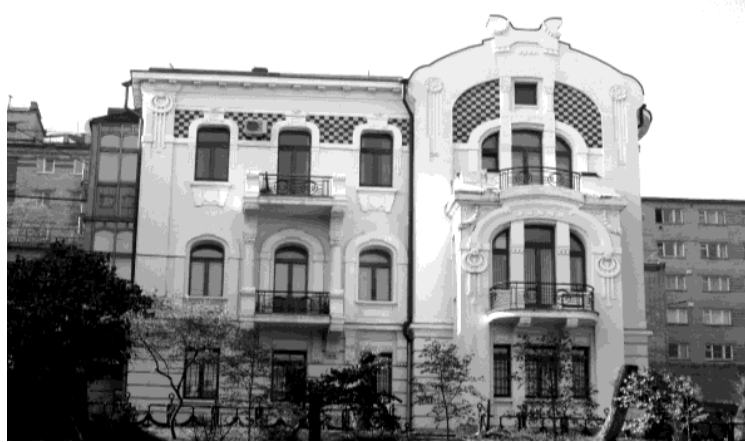

Fig. 6. Y.I. Briner's house (the architect G. Yunghendel) [Source: material from author private archive]
The trade links of Russia with China, Japan, and the United States rapidly developed. The status of Porto Franco attracted many representatives of the European traders and merchants of the first guild, such as de-Frieze, Kunst, Alberts, Demby, Cooper, Smith, Briner, Dattan, Lindgolm, and other entrepreneurs who were able not only to increase their fortune but also help the city in the development of navigation, the construction of the harbor with moorings and docks, city-building, and municipal improvements.

Looking at the architecture in Vladivostok since its formation and short-lived prosperity in the early $20^{\text {th }}$ century, it can be noted for its eclecticism, among which it is possible to select classic motifs, the "brick" style, the Neo-Russian style and Art Nouveau (Fig. 4, 5, 6, 7). In the central part of the city, manifestations of the German Gothic style are highly visible. At the turn of the $19^{\text {th }} / 20^{\text {th }}$ century, other European countries were represented in Vladivostok by Swiss, Danish, British, and French entrepreneurs, constructing buildings of trading houses, firms, residential mansions in accordance with their aesthetic preferences and thus leaving impact on the creation of an architectural image of the historic center of the city.

In the early $20^{\text {th }}$ century, the City Council banned the construction of wooden houses in the city center, as it was done in St. Petersburg, Moscow, and provincial cities. In the center of Vladivostok, solid construction of buildings on both sides of the streets in the style of the European architecture was carried out and not in the style of the Eastern architecture of such nearby countries as China, Korea, Japan. Many interesting wooden buildings, created in the late $19^{\text {th }}$ and early $20^{\text {th }}$ centuries, including in the style of Art Nouveau, unfortunately, were lost during the $20^{\text {th }}$ century. However, some buildings have survived to the present time.

The "face" of Vladivostok is turned to the sea. The sea and the picturesque mountainous landscape, "Hills of Manchuria", blocks of houses scattered on the slopes, give the city unique peculiarities, defining the shape of the city-fortress. The main facades of the historic center, located on the spurs of hills of the Eagle's Nest (the name is the same as in Port Arthur), are facing the south, to the Golden Horn Bay, or to the west, to Amur Bay.

In addition to urban mansions, separate holiday homes and other buildings for businessmen in Vladivostok stood out with interesting architecture and organic location in the natural landscape. The suburbs of Vladivostok were used as holiday suburbs. The distinctive feature of the prerevolutionary estates and dachas in the vicinity of Vladivostok was their location by the sea or in the 


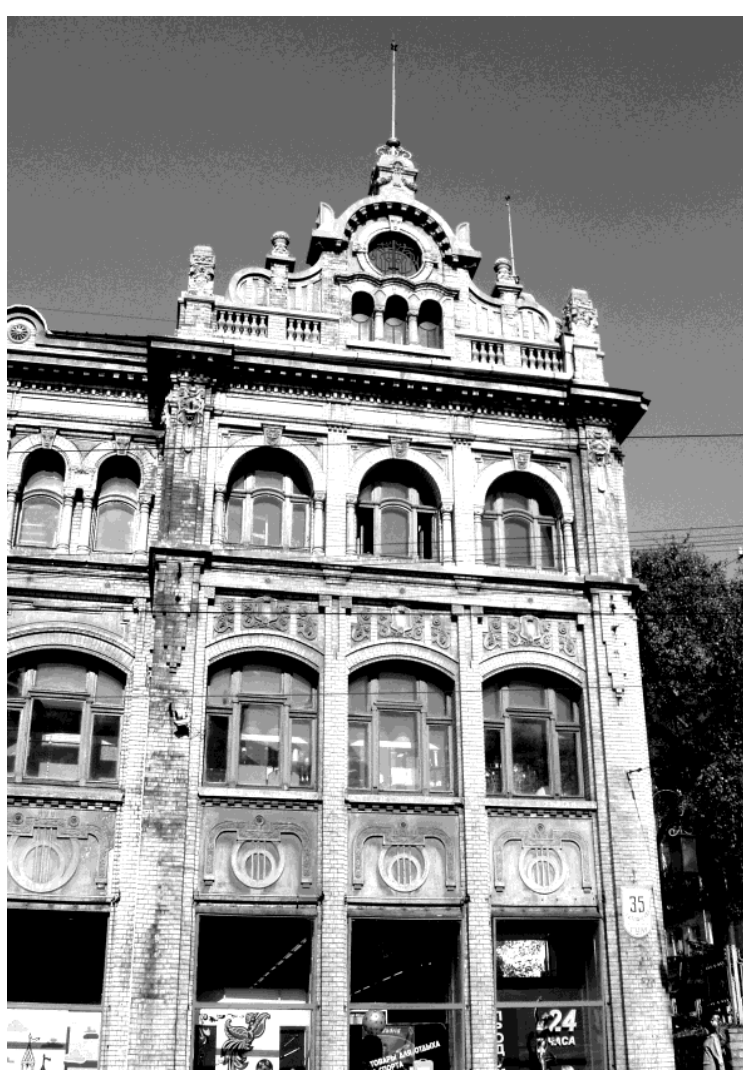

Fig. 7. The building of the Firm "Kunst and Albers" (the architect G. Yunghendel)

[Source: material from author private archive]

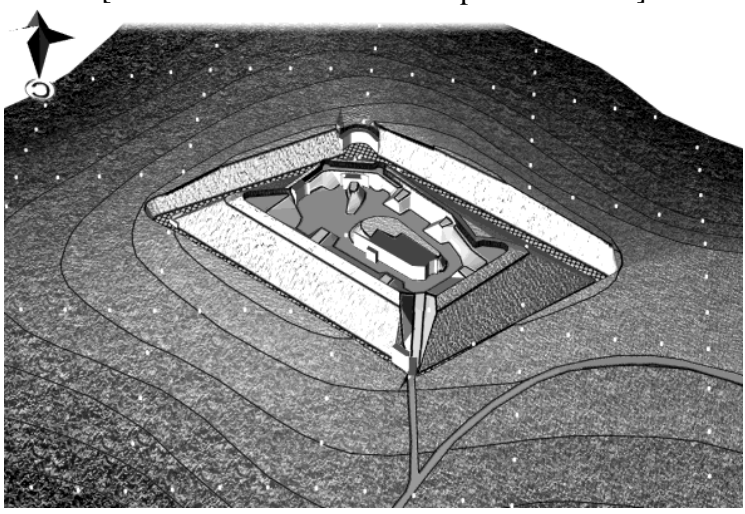

Fig. 8. Three-dimensional computer model of the Pospelov' Fort (Russky Island), project of 1899

[Source: material from author private archive]

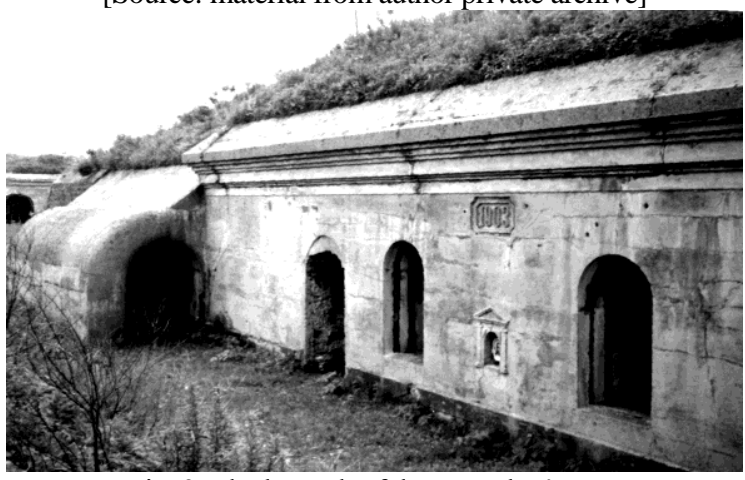

Fig. 9. The barrack of the Pospelov's Fort [Source: material from author private archive] immediate vicinity of the coast, surrounded by the picturesque natural landscape [15].

A decisive role in the urban planning was played by the construction of a grandiose complex of the Vladivostok Fortress [11, 16, 17].

By the early $20^{\text {th }}$ century, Vladivostok was reliving a construction boom; "on land across the Muravyov-Amursky Peninsula, on the hills in the city, on the coastal cliffs and islands - everywhere trees were uprooted, drilling, blowing up everywhere, bricks were laid and concreting everywhere as well; "the forts and batteries changed the overall picture of the city, from the romantic natural harbor it turned into a port worthy of its name" [18, 223-224].

As in Port Arthur, the author of the project of the long-term land by-pass in 1899 was C. I. Velichko. The project was approved on January 12, 1900, by Emperor Nicholas II. According to this project, in the early years of the $20^{\text {th }}$ century, forts and a number of other ground fortifications and redoubts were built in Vladivostok [8]. On average, the size of each fort is almost $200 \times 300$ meters, the area of the plot, bounded by a perimeter of the fortification is almost 4 hectares. The thickness of the walls and fortifications of the fortifications reaches approximately $0.9-1.2 \mathrm{~m}$. Most forts and fortifications are resolved as almost regular polygons surrounded by protective ditches in the perimeter (Fig. 8). Typical design is characteristic, many constituent parts of the forts on the different fortifications are almost identical, internal spaces isolated from each other are typical. Concrete casemate-like barracks serve as the centers of the compact compositions of the fortifications (Fig. 9), where in the design elements of the decor are used, borrowed from civil architecture; similar motifs are applied in the design of the caponier to roll-out arms (Fig. 10). To a large extent, the similarity of the fortresses of Port Arthur and Vladivostok is manifested in the concrete coastal artillery batteries, built at the turn of $19^{\text {th }} / 20^{\text {th }}$ centuries. The expressive exterior solutions and small, isolated interior with vaulted ceilings are typical.

The development of the city, remaining inside the ring of the fortifications and initially implemented as traditional orthogonal network blocks, by the early $20^{\text {th }}$ century became freer and more scenic, in accordance with the naturally rugged terrain. The diameter of the fortress is more than 10 kilometers, allowing to freely plan blocks of the city, extending to $4-5 \mathrm{~km}$. Closer to the wellfortified perimeter mostly barracks (Fig. 11) and other supporting constructions of the emerging fortress were constructed. 


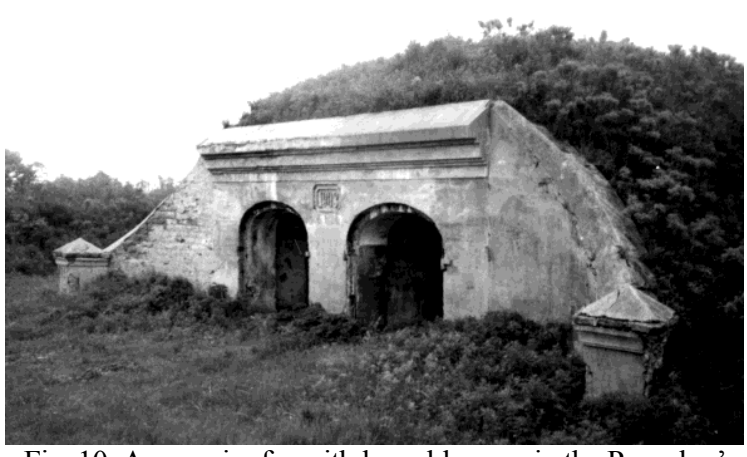

Fig. 10. A caponier for withdrawable guns in the Pospelov'

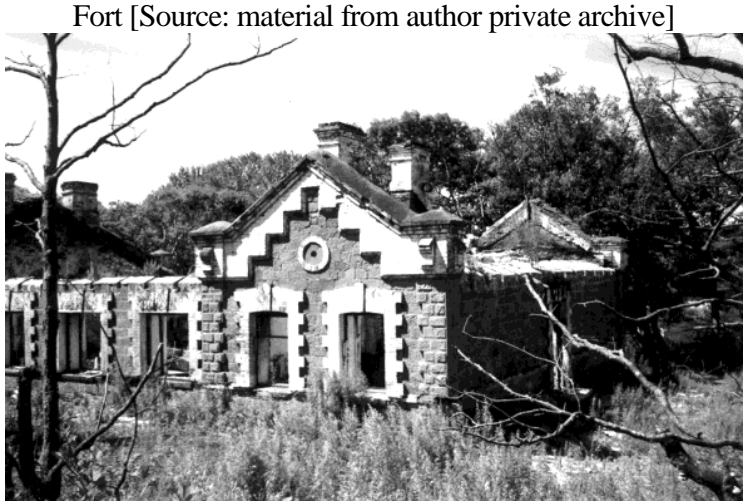

Fig. 11. A barrack (Russky Island)

[Source: material from author private archive]

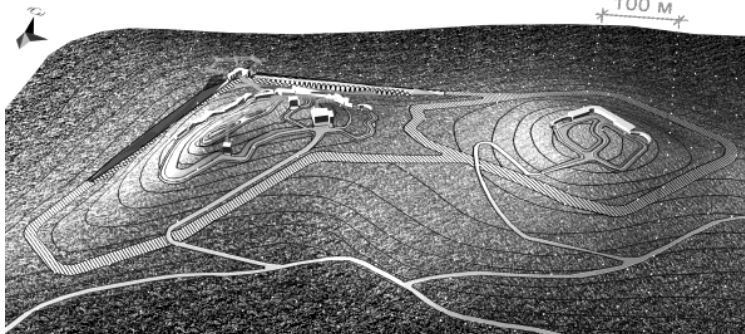

Fig. 12. Three-dimensional computer model of the fort № 7 with reference to the relief (Project of 1910)

[Source: material from author private archive]

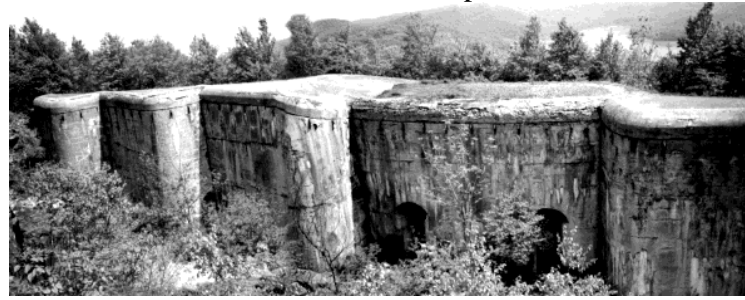

Fig. 13. Double coffer in the fort № 6

[Source: material from author private archive]

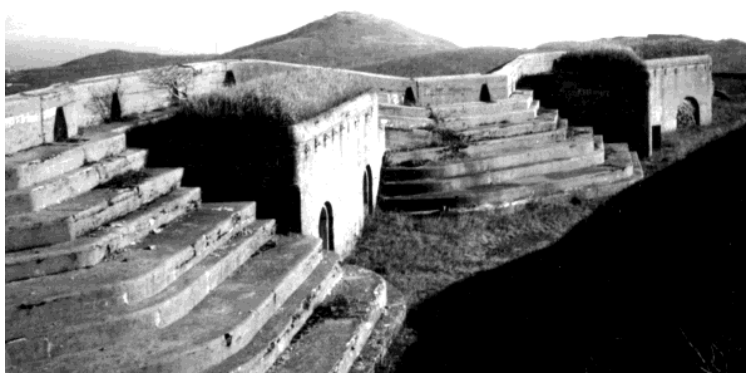

Fig. 14. A fragment of the parapet in the fort № 4

[Source: material from author private archive]
The fall of Port Arthur showed the need for the construction of a new type of fortifications to protect Vladivostok from land and sea. It became possible to create a grandiose and expensive project for strengthening defense of the fortress in 1910 . Military engineers have built a project on strengthening the defense of the fortress, Utopian in its grandiosity. Implementation of the project in 1910 was estimated at 98 million imperial roubles; even in 1915, during the First World War, almost 14 million roubles were awarded, while the construction of the fortress Port Arthur amounted to 4.25 million roubles $[19,20]$. The size of the land bypass of the fortress in diameter rose up to 24-26 $\mathrm{km}$. In 1910-1916 under the project, developed in the leadership of Engineer-General A. P. Vernander, the forts No. 1-7 were constructed on the southern border of the Sedanka River, the forts No. 9-12 on the Russian Island and other fortifications. These fortifications include casemate-like and underground structures; thickness of the concrete covers reaches 2.4-3.6 m. The constructions of the Vladivostok Fortress include the aggregate of 11 concrete forts, 9 defense points, about 50 artillery batteries and coastal caponiers. During the construction of the Vladivostok Fortress, it was expected to implement about $500000 \mathrm{~m}^{3}$ concrete and about $60 \%$ concrete works [3, 21].

The magnitude of the new challenges led to the technical impossibility of performance of the project in the framework of the previous principles, the layout of the huge area of forts on the tops of the steep hills was forced to be determined by the terrain, obeying it (Fig. 12). Physically enlarging, the dimensions of the fortifications became relatively smaller to the total area of the fortress. The size of each fort was approximately 300-700 meters, the average area of the plot, bounded by the perimeter of the fortification exceeds 13 hectares. The thickness of the walls and covers has increased two or three times. An asymmetric, complex spatial organization of the fortifications, due to their binding to relief, is characteristic. A vast and extensive internal communication space of the corridor type binds individual fortification of the fort, scattered on its surface and remote from each other. These small underground towns, capable of autonomous existence during the siege, are located under a group of separately standing buildings (coffres, Fig. 13, barracks, caponiers, concrete parapets with internal galleries, Fig. 14). The principle of construction of each fort has its own vector thrust, the central core of the composition of the forts, as in the project of 1899, serve as their barracks. The spaces had different functions: residential barracks, coffres and caponiers - martial, internal galleries served as shelters, places of worship were spaces near kiots with icons, etc.. 


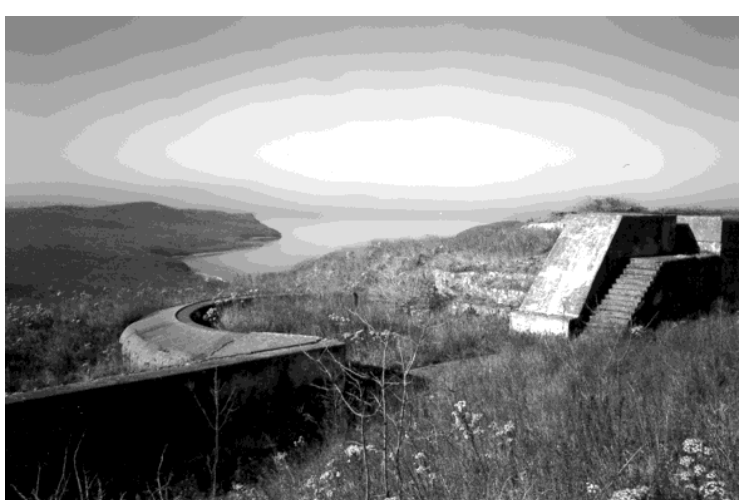

Fig. 15. The view from the fort № 9 (Russky Island) to the Gulf of Peter the Great

[Source: material from author private archive]

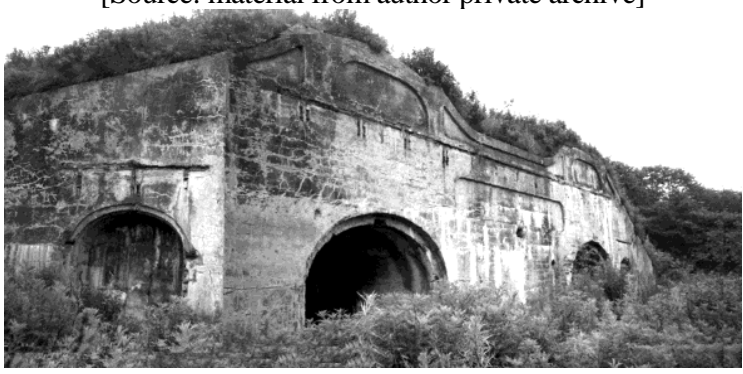

Fig. 16. A coast caponier for withdrawable guns (Russky Island)

[Source: material from author private archive]

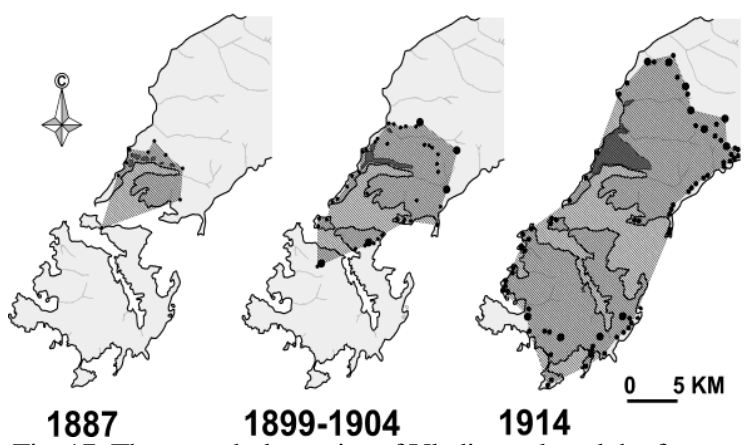

Fig. 17. The growth dynamics of Vladivostok and the fortress on the Muravyov-Amursky' peninsula and the Russky Island

[Source: material from author private archive]

The new fortifications have different proportions, their walls and covers are much more massive and often feature additional stone. The new coastal batteries differ by more than simple exterior solutions, their entrances are covered by knee-type vestibules. The massive walls and covers are significantly increased, covered by the earth, most of the inner spaces are connected by communications galleries, penetrating the concrete array of batteries along its entire length.

The fortifications were from cast-in-place concrete, internal galleries, niches for shooters and armored turrets were built in. The architecture was more and more "buried" under the ground, the internal spaces connected among themselves were increased. The facades of the fortifications facing the rear are hidden in the folds of the terrain. Near the buildings hidden under slopes, overgrown with shrubs and grass, as the exterior, there were only individual facades left. A general trend towards minimizing of the exteriors of relatively extensive multi-level, interconnected with each other interior spaces is characteristic. This approach has had a direct impact on the entire look of the buildings, very substantially changing their composition and proportions, exteriors and interiors. There were qualitative, topological changes and the transformation of the morphology of the fortifications. The constructions of the fortress visually demonstrate the plastic possibilities of the concrete casting with unified work of all elements of the structure with the new architecture without a clear division into the load bearing parts and loads being carried parts. The massive forms were created in the organic unity with the surrounding landscape (Fig. 15). The landscape and spatial organization of maritime fortresses are directly linked to the rugged terrain of the coast, which is typical of terrain with high cliffs, deep coves, and capes. This explains many features of the architecture of such seaside fortresses, built of which are similar to the fortifications, erected in the mountains. The complex three-dimensional compositions of the fortifications, correlated with the outlines of the natural topography, represent the current architecture and landscape environment. The originality of the architecture of fortresses of this period is associated with the transition from the building of brick and stone structures to the creation of sophisticated complexes of monolithic concrete. The visually nonfunctional prints of selected popular architectural styles of these times on the facades of some fortification building are characteristic as well (Fig. 16). The fortifications bear the features of the original Art Nouveau and, partly, the traditional classical style.

The names of the forts of the Vladivostok Fortress symbolized the historical continuity and the indissoluble link of Vladivostok with the Russian Empire (such as the forts of Prince Rurik, Prince Oleg, Saint Grand Prince Vladimir, Grand Prince Dmitry Donskoy, Tsar Ivan the Terrible, Emperor Peter the Great, Empress Catherine the Great, Emperor Alexander the Blessed, Emperor Alexander the Liberator, Heir Tsarevich Alexei Nikolayevich).

Around the military settlement, the sphere of services and social infrastructure was emerging [22]. The growing city absorbed many of the old fortifications, its boundaries extended under the protection of the fortress, the road and street system developed. Vladivostok is now under the protection of two rings of fortifications (Fig. 17). The railway branches were built, the system of suspended cable roads, electricity, and drainage systems were created, a wireless telegraph operated. Airfields with hangars for aerostats and airplanes were 
built. The road system of the fortress emerged and improved which now connect many districts of the modern city. In 1908, the water supply scheme was developed for the fortress, later having an influence on the development of Vladivostok. As in Port Arthur, in Vladivostok, there are holiday areas outside the fortress, located in the forest and the coastal areas, mainly, to the northwest of the city.

With the development of the city, the system of its fortifications provided a considerable mutual influence on each other, growing consistently until the early $20^{\text {th }}$ century. Therefore, the fortress of Vladivostok is an integral part of the present city environment.

The beginning of World War I, the following Civil War, and the events of 1917 resulted in a giant construction which, sometimes almost concluded, was frozen. In 1918, there was the intervention of Vladivostok by American and Japanese armed forces. The latest fortifications were in foreign hands. It is known that the interveners praised the Vladivostok fortresses this way, "This fortress is the best maritime fortress around the world, and its fortifications are themselves are positively a miracle of military and engineering art" [20].

In the $20^{\text {th }}$ century, Vladivostok has passed specific stages in the development of architecture in the Soviet period - constructivism and moving to the pompous and representative Stalinist architecture that resulted in emerging of the most distant from the capital "Stalin Empire Style" on the shore of the Pacific Ocean. Sad pages in the life of the city of the 1930s are associated with expulsion camps from which prisoners by ships were sent to Magadan, Kolyma, and Chukotka.

Throughout its history, Vladivostok repeatedly became the Russian polygon for implementation of the ambitious urban development plans. Currently, the new city's development program is implemented with the domestication of the adjacent island areas and the construction of large-span bridges of various designs. The dimensions of the bridges are characterized by values such as the span length up to $1104 \mathrm{~m}$, the height of the pylon - up to $320 \mathrm{~m}$ and the total length of the flyover - up to $3100 \mathrm{~m}$. In fact, many large-scale ideas of the 1930s-1950s revived at a new level for the development of Vladivostok. This is due to the Forum of the countries of the Asiatic-Pacific region held in September 2012 and it gives a new, positive impetus to the development of the entire Far East region and Vladivostok, the remaining the outpost of Russia in the Pacific Ocean.

The expansion, carried out by the Russian Empire, extending to the East, culminated in the $20^{\text {th }}$ century. The fortress Port Arthur was one ring of forts and shore batteries around the city corresponding with the coastal mountainous landscape. In Vladivostok, we have also implemented the scheme of the emerging of the city and fortresses in the rigid dependence on the structure of the terrain where the boundaries of the protected perimeter were identified by the local geomorphology, and the fortifications were located on the tops of hills for better control over the terrain. These are the basic principles of the urban development of Port Arthur and Vladivostok. The fortress of Vladivostok under the draft of 1899 is very close to Port Arthur's spiritual ideas, implemented in the first years of the $20^{\text {th }}$ century. After the fall of Port Arthur, Vladivostok began to intensively fortified, and here there was a second ring of fortifications, which still far exceeds the size of the modern city. The giant fortress of Vladivostok was the last marine fortress built by the Russian Empire but remained unfinished and turned into a Utopia. The existing fortifications of the Vladivostok Fortress are declared a monument of history and militarydefensive architecture of federal significance.

The main factor in the form creation of fortresses has always been their function but the architectural solutions were determined by the technical and technological techniques used to create the fortress. The turbulent processes of the turn of the centuries, the replacement of the defensive paradigm, construction, and architectural concepts, and aesthetic views, innovations of that time - all this was reflected in the architectural appearance of the marine fortresses. Features of the architecture are due to the fusion of features defined by its function, the complexity of the terrain, the applied technological solutions, architectural traditions, and innovations. The traditions that were characterized, first of all, by the use of elements of stylistics and decor, widely used in civil architecture, disappeared and gave way to work with large masses and volumes which became actively used means of artistic expresion and gave rise to new architectural solutions. The technological effectiveness, functionality, and rationality of solutions, manifested in the architectural rigor of the forms of fortresses of this period, increased.

The concrete defensive architecture of the late $19^{\text {th }}$ - early $20^{\text {th }}$ centuries became a special architectural phenomenon and the last link in the centuries-old evolution of fortresses. For several years, there has been a rapid transition from compact compositions in the form of regular polygons with small buildings, which include isolated inner spaces, to extensive and complex asymmetric complexes with a vector orientation of plans, large architectural masses and volumes, with a tendency to minimize exteriors and the development of extended multi-level, connecting internal spaces. Difficult in their spatial organization, cast from concrete, the new fortifications with their vanishing exterior and branched internal structure marked the end of the era of fortress construction. 


\section{References}

1. Сивов Е.В. Из истории Николаевска-на-Амуре (1850-1917 гг.). Ленинское знамя, 1963 , с. 82-97.

2. Горнова М.И. Крепость на мысе Чныррах. Памятники Отечества, 1984, № 2(10), с. 80-83.

3. Яковлев В.В. Приморские крепости. Отдел курса «Береговая оборона» Военно-морского факультета Военно морской академии Р.-К.К.Ф. Ленинград: Издание военно-морской академии Р.-К. К.Ф., 1926.247 с.

4. Яковлев В.В. История крепостей. Санкт-Петербург: Полигон, 1995. 397 с.

5. Крадин Н.П. Дальний (Далян) город европейского типа на востоке Азии. Архитектурное наследство, 2003, № 45 , с. $162-173$.

6. Левошко С.С. Город Дальний в истории российского градостроительства в Маньчжурии. Россия и АТР, 2000, № 4, c. 96-107.

7. Порт-Артур. Воспоминания участников. Нью-Йорк: Издательство им. Чехова (Chekhov Publishing Ноuse of the East European Fund, Inc.), 1955. 412 c.

8. Аюшин Н.Б., Калинин В.И., Воробьев С.А., Гаврилкин Н.В. Владивостокская крепость. Владивосток: Дальнаука, 2006. 336 с.

9. Касьянов Н.В. Крепость Владивосток - памятник Российского военно-оборонительного зодчества конца XIX и начала XX века. Архитектурное наследство, Москва: Editorial URSS, 2006, Выпуск 46, с. $269-288$.

10. Марков В. М. Путеводитель по Владивостоку. Владивосток: Дальневосточное книжное издательство, 1993. $240 \mathrm{c}$.

11. Касьянов Н.В. Владивостокская крепость. Между прошльмм и будущиим.Владивосток: ДВГТУ, 2001.100 с.

12. Памятники истории и культуры Приморского края. Материаль к своду. Владивосток: Институт истории ДВО РАН, 1991. $268 \mathrm{c}$

13. Ингемансон Б. Потерянный рай. Имение Новогеоргиевское, 1892-1922. Россия и ATP, 2001 , № 4, с. 23.

14. Анча А.А., Калинин В.И., Позняк Т.З. Владивосток в фотографиях Меррилла Хаскелла. 11 августа 1919 23 февраля 1920. Хабаровск: Риотип, 2009, с. 14.

15. Касьянов Н.В. Приморские имения в окрестностях Владивостока на рубеже XIX-XX веков. Русская усадьба, 2005, Выпуск 11 (27), с. 271-286.

16. Обертас В.А. Формирование планировочной структуры Владивостока в ХІХ в. Архитектурное наследство, 1976 , № 25, c. 85-93.

17. Касьянов Н.В. Владивостокская крепость: архитектурно-исторический аспект. Вестник ДВО РАН, 2002 , № 1, c. $72-84$.

18. Деег Л. Кунст и Альберс. Владивосток. История немецкого торгового дома на российском Дальнем Востоке (1864-1924). Владивосток, Издательство Приморского полиграфкомбината, 2002.

19. Ргвиа, Ф. 802 , Оп. 5, Д. 16816, Л. 143.

20. Яковлев В.В. Фортификация. Вып. III, Устройство крепостей в начале ХХ столетия; участие их в мировой войне и современное положение вопроса о них. Ленинград.: Издание Военно-Инженерной академии РККА, $1925.216 \mathrm{c}$.

21. Ргвиа, Ф. 802, Оп. 5, Д. 16816.

22. Обертас В.А. Формирование планировочной структуры Владивостока в ХІХ в. Архитектурное наследство, 1976, № 25, c. $85-93$.

INFORMATION ABOUT THE AUTHOR:

Kasyanov Nikolay Vladimirovich. Born in 1973, Leningrad. Educational background: 1993-1999 Architectural Institute of the Far Eastern State Technical University (Arch IDVGTU), now part of the Far Eastern Federal University), diploma with honors. 1999-2002 the postgraduate program. Since $2004-$ a candidate of architecture. Employment: 1999-2004 the teaching staff, Arch DVGTU, Vladivostok. Since 2004 - Senior Research Fellow, Scientific Research Institute of Theory of Architecture and Urban Planning (NIITIAG), Moscow. Since 2006 - Head of Lab of Architectural Form Creation, NIITIAG. The author of more than 50 published works, with experience of design works.

Scientific interests: form creation in architecture and nature, innovative technologies in architecture, fortress architecture. 105264 Moscow, ул. 7-я Парковая, д. 21-a, tel/fax 8 (495) 9650255 , phone 891513879 72, E-mail: kas_nv@mail.ru

Kopsavilkums. Militāra rakstura nocietinājumi pasaules pilsētbūvniecības vēsturē ienesa jaunu būvniecības tehnologiiju un arhitektūras formveides izteiksmi. 19. gs. beigās krievu militārā padome nonāca pie secinājuma, ka tradicionālā ķieǵel̦u mūru nocietinājumiem nav tik lielas noturības, kā tas ir raksturīgs monolītā betona mūrim. Krievijas impērijai piederēja vairākas pilsētas ar piekrastes nocietinājumiem pie Baltijas jūras, Melnās jūras un Klusajā okeānā. Gar Klusā okeāna piekrasti nocietinājumi bija Ohotskas, Petropavlovskas-Kamčatkas, Nikolajevas pie Amūras, Vladivostokas, Arturas ostām, kas liecināja par ḷoti nopietnu valsts militārās varen̄ibas attīstîbu. Tālākais nocietinājuma punkts austrumos bija neaizsalstošā Arturas osta. Tās būvniecības plāns1898. g. paredzēja ostas pilsētas-nocietinājumu izvietot kalnainā vietā ap $200 \mathrm{~m}$ v. j. līmeņa, tai pievienojot $70 \mathrm{~km}$ sasaisti ar sauszemes ceļu un izvietojot ne mazāk par 70 tūkst. vīru lielu karaspēku. 1904. g. bija izbūvēta jau puse no pilsētas nocietinājuma. 1904. gada beigās japāņu kara laikā cietoksnis tika ieņemts. Attīstoties kug̣niecībai un tirdzniecības Tālo Austrumu zemēs, strauju izaugsmi 
aizsāka netālā dienvidrietumu daḷas osta - Vladivostoka. Pilsēta jau 19.gs. beigās bija pārmantojusi Eiropas kultūras tendences, kuru aktīvi ienesa krievu militārā vadība, arhitekti, vairāki vācu būvinženieri. Aktīva kuğniecība un tirdzniecība ar Japānu, K̦īnu un Ameriku nesa strauju Vladivostokas attīstību.

Jau 19.gs.beigās pilsētas apbūvē ir nolasāms dažādu arhitektūras stilu sajaukums, kas nācis līdz ar Vakareiropas tirgotāju un kuǵotāju apmešanos pilsētā - eklektika, klasicisms, ķieǵeḷu arhitektūra, modernisms. Pilsētas centrā vairāk dominē gotiskā stila tendences. 20.gs. sāk. pilsētā aizsākas nocietinājumu būvniecība, kur katra forta lielums ir aptuveni 200x300 m, bet aizsargsienas biezums sasniedza 0.9-1.2 m. Nocietinājumu iekšpusē ir izvietojusies pilsētas apbūves kvartāli. Tuvāk nocietinājumu perimetram atradās kazarmas. 1910. gadā aizsākās nocietinājumu pastiprināšana, mūrus uzbiezinot pat 2-3 reizes. Katrā no milzu būvapjomiem atradās galerijas un kaujas nišas. Nocietinājumu līnija tika slēpta aiz reljefa, kokiem, zālienā, tikai vietām atsedzot mūra laukumu. Ap pilsētas militāro infrastruktūru gredzenveidā attīstījās tās apkalpojošā struktūra, tā pilsētai pamazām veidojot savu urbānās telpas raksturu. Līdz ar cariskās valdības gāšanu 1917. gadā noslēdzās militāro nocietinājumu būvniecības laiks Krievijā. 